\title{
Consumption of onions and a reduced risk of stomach carcinoma.
}

Citation for published version (APA):

Dorant, E., van den Brandt, P. A., Goldbohm, R. A., \& Sturmans, F. (1996). Consumption of onions and a reduced risk of stomach carcinoma. Gastroenterology, 110, 12-20.

https://doi.org/10.1053/gast.1996.v110.pm8536847

Document status and date:

Published: 01/01/1996

DOI:

10.1053/gast.1996.v110.pm8536847

Document Version:

Publisher's PDF, also known as Version of record

\section{Please check the document version of this publication:}

- A submitted manuscript is the version of the article upon submission and before peer-review. There can be important differences between the submitted version and the official published version of record.

People interested in the research are advised to contact the author for the final version of the publication, or visit the DOI to the publisher's website.

- The final author version and the galley proof are versions of the publication after peer review.

- The final published version features the final layout of the paper including the volume, issue and page numbers.

Link to publication

\footnotetext{
General rights rights.

- You may freely distribute the URL identifying the publication in the public portal. please follow below link for the End User Agreement:

www.umlib.nl/taverne-license

Take down policy

If you believe that this document breaches copyright please contact us at:

repository@maastrichtuniversity.nl

providing details and we will investigate your claim.
}

Copyright and moral rights for the publications made accessible in the public portal are retained by the authors and/or other copyright owners and it is a condition of accessing publications that users recognise and abide by the legal requirements associated with these

- Users may download and print one copy of any publication from the public portal for the purpose of private study or research.

- You may not further distribute the material or use it for any profit-making activity or commercial gain

If the publication is distributed under the terms of Article $25 \mathrm{fa}$ of the Dutch Copyright Act, indicated by the "Taverne" license above, 


\title{
Consumption of Onions and a Reduced Risk of Stomach Carcinoma
}

\author{
ELISABETH DORANT,* PIET A. VAN DEN BRANDT,* R. ALEXANDRA GOLDBOHM, ${ }^{*}{ }^{*}$ \\ and FERD STURMANS* \\ *Department of Epidemiology, University of Limburg, Maastricht; and ${ }^{\star}$ Department of Epidemiology, TNO Nutrition \\ and Food Research Institute, Zeist, The Netherlands
}

Background \& Aims: Results from case-control studies and laboratory tests indicate that consumption of allium vegetables may considerably reduce the risk of stomach cancer. The association between onion and leek consumption, garlic supplement use, and the incidence of stomach carcinoma was studied. Methods: The association was investigated in the Netherlands Cohort Study on diet and cancer, which started in 1986 with 120,852 men and women ranging in age from 55 to 69 years. Dietary data were available for 139 stomach carcinoma cases diagnosed during 3.3 years of follow-up and for 3123 subjects of the randomly selected subcohort. Results: The rate ratio for stomach carcinoma in the highest onion consumption category ( $\geq 0.5$ onions/day) was 0.50 ( $95 \%$ confidence interval, $0.26-0.95$ ) compared with the lowest category ( 0 onions/day) after adjustment for other risk factors. The reduction in risk was restricted to carcinoma in the noncardia part of the stomach $(P=0.002)$ and was also found among subjects without a history of stomach disorders $(P=0.01)$. The consumption of leeks and the use of garlic supplements were not associated with stomach carcinoma risk. Conclusions: The Netherlands Cohort Study provides evidence for a strong inverse association between onion consumption and stomach carcinoma incidence.

$T$ he consumption of vegetables and fruits is consistently associated with a reduced risk of stomach cancer. In recent reviews of the literature, it was concluded that the most abundant evidence for an inverse association is available for fruit and lettuce. However, allium vegetables, particularly onions, may be protective as well. ${ }^{1-4}$

Allium vegetables, such as garlic and onions, are traditionally known for their antibacterial and fungicidal properties. Most of their prophylactic and therapeutic effects are ascribed to specific sulfur-containing compounds, which are responsible for the typical odor and flavor of these plants. ${ }^{5-7}$ Some of these so-called organo- sulfur compounds also act as antimutagens in in vitro models and even as anticarcinogens in in vivo test systems. ${ }^{8}$ Organosulfur compounds have been detected in raw and cooked allium vegetables and in commercial preparations such as garlic supplements, the most widely used type of dietary supplement by elderly persons in The Netherlands. ${ }^{9-11}$ Other potentially anticarcinogenic compounds in allium vegetables are the flavonols quercetin (onions) and kaempferol (leek, garlic) and the cysteine-containing tripeptide glutathione (onions), which plays an important role in the detoxification of carcinogens. ${ }^{12-17}$

Evidence that allium vegetable consumption is associated with a reduction of stomach cancer risk in humans is at present based on results from case-control studies performed in different parts of the world that have evaluated allium vegetables as a distinct vegetable category. Most of these case-control studies reported a decreasing risk for stomach cancer with increasing consumption of allium vegetables, although not with all types of alliums or for all subsites or histological subtypes of stomach cancer. ${ }^{18-29}$ Two studies found no association with onions, chives, or garlic, ${ }^{30,31}$ and one case-control study reported a higher risk for stomach cancer with increasing frequency of onion intake. ${ }^{32}$

However, the results from case-control studies can be biased by differential recall of dietary intake due to awareness of the disease status. ${ }^{33}$ Recall of dietary intake could also have been influenced by current dietary habits, ${ }^{34}$ which may be different from those in the relevant reference period due to symptoms of the disease. ${ }^{35,36}$ Prospective studies are less susceptible to recall bias because dietary intake is measured before the presence of disease is known.

\footnotetext{
Abbreviations used in this paper: NLCS, Netherlands Cohort Study; $\mathrm{OR}$, odds ratio; $\mathrm{RR}$, rate ratio.

(C) 1996 by the American Gastroenterological Association 0016-5085/96/\$3.00
} 
In the Netherlands Cohort Study (NLCS), a large-scale prospective cohort study on diet and cancer that began in 1986 with 120,852 men and women, we have examined the association between the consumption of onions and leeks, the use of garlic supplements, and the subsequent risk of carcinoma in the stomach and subsites within the stomach after 3.3 years of follow-up. To evaluate whether the results were biased due to changes in dietary habits caused by prediagnostic cancer-related symptoms, we also performed analysis with exclusion of cases diagnosed during the first year after baseline.

\section{Materials and Methods}

\section{The NLCS}

A description of the design of the NLCS and the characteristics of the cohort have been published. ${ }^{37}$ In brief, the NLCS began in 1986 with 58,279 men and 62,573 women ranging in age from 55 to 69 years, originating from 204 municipalities in The Netherlands with computerized population registries. A self-administered mailed questionnaire was used to collect information on usual diet, lifestyle characteristics, medical history, dietary supplement use, and other important risk factors for cancer. Following the case-cohort approach for analysis of the study, a subcohort of 3500 subjects (1688 men and 1812 women) was randomly sampled from the large cohort and followed up for vital status. The entire cohort has been followed up for the incidence of cancer.

\section{Follow-up for the Incidence of Cancer}

Information on cancer incidence has been collected for the entire cohort by record linkage with all nine cancer registries in The Netherlands and with PALGA, the Dutch Network and National Database for Pathology. The method of record linkage has been published. ${ }^{38}$ The present analysis is restricted to cancer incidence in the first 3.3 years of followup (from baseline in September 1986 to December 1989). Completeness of follow-up in this period was estimated to be $95 \%{ }^{39}$

\section{Population for Analysis}

After excluding subjects reporting any prevalent cancer other than skin cancer or with incident in situ carcinoma, stomach cancer other than carcinoma (sarcoma, lymphoma, unspecified morphology), or without a microscopically confirmed diagnosis, 155 incident primary stomach carcinoma cases were available for analysis. From the subcohort, 3346 persons remained for analysis after excluding prevalent cancer cases other than skin cancer.

\section{Questionnaire}

A 150-item semiquantitative food frequency questionnaire was used to collect information on the usual intake of foods and beverages in the year preceding the start of the study. ${ }^{40}$ Questionnaire data of all cases and subcohort members have been key-entered twice and processed blinded with respect to case/subcohort status to prevent random and systematic coding errors.

Two of the questions on vegetable intake specifically focused on the consumption of allium vegetables: "how many onions did you usually eat per week?" and "how often have you consumed leek in summer and how often in winter?". Consumption of leeks was estimated on a scale of six categories per season, ranging from "never or less than once per month" to "3-7 times per week," including leeks consumed in mixed vegetable dishes. A question on the consumption of other allium vegetables, such as garlic, chives, or shallots, was not included in the baseline questionnaire. The questionnaire has been validated against three 3-day diet records. ${ }^{40}$

Information on the use of dietary supplements was collected with an open-ended question that was formulated as follows: "during the past 5 years, did you use vitamin tablets, drops, or other preparations (for example, tonics, vitamins, garlic pills, brewers' yeast, calcium)?" For each of the maximal four supplements that could be listed, information on the type of supplement, brand name, dose per day, and the period in which the consumption took place could be listed. Recall of garlic supplement use was evaluated by comparing questionnaire data with information from three personal interviews as reference. ${ }^{41}$

\section{Data Analysis}

For the analysis of onion and leek consumption, we used the data of 139 case patients (106 men and 33 women) and 3123 subcohort members ( 1525 men and 1598 women) for whom complete dietary data were available. ${ }^{39}$ Subjects were categorized into four categories of onion consumption $(0$, $\leq 0.25,0.25-0.5$, and $\geq 0.5$ onions per day) and three categories of leek consumption $(0, \leq 2$, and $>2$ times per month).

Analyses of garlic supplement use are based on 152 case patients (119 men and 33 women) and 3340 subcohort members (1627 men and 1713 women) with complete information on dietary supplement use. Garlic supplement users were defined as those subjects who reported daily use of any garlic supplement for at least 1 year in the 5 -year period before baseline. When garlic supplement users also took other dietary supplements in the same time period, we separately examined the relation with stomach carcinoma for users of exclusively garlic supplements with nonusers as reference and for those consuming garlic supplements together with other supplements. For the latter analysis, we used subjects taking any other supplement as reference.

Case-cohort analyses were performed based on the assumption that survival times were exponentially distributed in this follow-up period. ${ }^{39}$ The methods developed for the analyses, allowing for the additional variance introduced by the subcohort sampling, were based on Cox's partial likelihood. ${ }^{42}$ In age/sex-stratified analyses, we computed Mantel-Haenszel rate ratios (RRs) and 95\% confidence intervals for onion and leek consumption and for garlic supplement use and tests for 
Table 1. Distribution of Stomach Carcinoma Case Patients and Subcohort Members Across Categories of Onion and Leek Consumption and Garlic Supplement Use

\begin{tabular}{|c|c|c|c|c|c|c|}
\hline \multirow[b]{3}{*}{ Allium consumption } & \multicolumn{5}{|c|}{ Case patients (\%) } & \multirow[b]{3}{*}{ Subcohort (\%) } \\
\hline & \multirow[b]{2}{*}{ All } & \multicolumn{4}{|c|}{ Year of follow-up } & \\
\hline & & 1 & 2 & 3 & 4 & \\
\hline Onion consumption (no./day) & $(n=139)$ & $(n=35)$ & $(n=42)$ & $(n=42)$ & $(n=20)$ & $(n=3123)$ \\
\hline 0 & 28.8 & 25.7 & 28.6 & 26.2 & 40.0 & 20.7 \\
\hline$\leq 0.25$ & 29.5 & 37.1 & 28.6 & 28.6 & 20.0 & 29.5 \\
\hline $0.25-0.5$ & 31.7 & 28.6 & 33.3 & 33.3 & 30.0 & 35.2 \\
\hline$\geq 0.5$ & 10.1 & 8.6 & 9.5 & 11.9 & 10.0 & 14.7 \\
\hline Leek consumption (frequency/mo) & $(n=139)$ & $(n=35)$ & $(n=42)$ & $(n=42)$ & $(n=20)$ & $(\mathrm{n}=3123)$ \\
\hline 0 & 33.1 & 31.4 & 38.1 & 31.0 & 30.0 & 30.6 \\
\hline$\leq 2$ & 47.5 & 57.1 & 42.9 & 38.1 & 60.0 & 38.8 \\
\hline$>2$ & 19.4 & 11.4 & 19.0 & 31.0 & 10.0 & 30.6 \\
\hline Garlic supplement use ${ }^{a}$ & $(n=152)$ & $(n=40)$ & $(n=47)$ & $(n=45)$ & $(n=20)$ & $(\mathrm{n}=3340)$ \\
\hline No & 77.6 & 80.0 & 68.1 & 84.4 & 80.0 & 71.0 \\
\hline Exclusively garlic & 5.9 & 5.0 & 8.5 & 6.7 & 0 & 4.6 \\
\hline Any other supplement & 13.2 & 15.0 & 17.0 & 6.7 & 15.0 & 20.2 \\
\hline Garlic + any other supplement & 3.3 & 0 & 6.4 & 2.2 & 5.0 & 4.2 \\
\hline
\end{tabular}

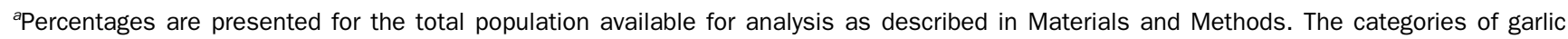
supplement use are mutually exclusive.

trend in the RRs. In the multivariable analyses, we further adjusted for alcohol intake, dietary intake of vitamin $C$ and $\beta$-carotene, smoking status, educational level, a history of stomach disorders, and a family history of stomach cancer. The dietary intake of vitamin $C$ and $\beta$-carotene was computed by using the Dutch food composition table. ${ }^{43}$ All $95 \%$ confidence intervals were corrected for the additional sampling variance. Tests for trends in the RRs were based on likelihood ratio tests.

Because the pathogenesis of carcinoma in the proximal part of the stomach (cardia and gastroesophageal junction) is different from that in the other part of the stomach ${ }^{44}$ and because there may be subsite-specific differences in stomach carcinoma risk associated with allium vegetable consumption, ${ }^{25}$ we also evaluated whether the role of onion and leek consumption varies for the cardia (ICD-O topography code 1510) and the other subsites (ICD-O topography codes $1511-1519) .{ }^{45}$ To evaluate a potential influence of prediagnostic symptoms of stomach carcinoma on dietary habits, analyses were also performed for cases diagnosed after the first year of follow-up. Because other gastric diseases (e.g., ulcer disease, gastritis) might have influenced dietary habits as well ${ }^{36}$ and may also play a role in gastric cancer etiology, ${ }^{46}$ analyses were also performed for those subjects who did not report any gastric disorders requiring medical attention.

\section{Results}

Table 1 shows the distribution of onion and leek consumption among subcohort members and case patients ranked by year of follow-up. Overall, the consumption of onions was lower among case patients than among subcohort members. The proportion of case patients in the highest consumption category increased somewhat in later follow-up years, but the proportions were still lower than in the subcohort. Leeks were less frequently consumed by case patients than by subcohort members. No clear trends were found after categorization of the case patients by year of follow-up. A slightly larger proportion of case patients than subcohort members used garlic supplements $(9.2 \%$ and $8.8 \%$, respectively). The proportion of case patients using garlic supplements varied considerably between the follow-up years with no indication of an association with prediagnostic symptoms of stomach carcinoma.

Associations between onion and leek consumption, garlic supplement use, and potential risk factors for stomach cancer (age, sex, dietary intake of vitamin $C$ and $\beta$ carotene, alcohol intake, smoking status, and educational level) were reported earlier. ${ }^{47,48}$ One of the two other risk factors for stomach cancer, a personal history of stomach disorders (defined as any stomach disease in the past that required medical attention), was associated with onion and leek consumption and the use of garlic supplements. A higher proportion of subcohort members who did not consume onions, leeks, or garlic supplements reported having a stomach disorder $(11.9 \%, 11.2 \%$, and $10.3 \%$, respectively) compared with subjects in the highest onion and leek intake categories and among users of garlic supplements $(9.4 \%, 8.7 \%$, and $7.2 \%$, respectively). The associations were less marked for a family history of stomach cancer; $7.7 \%$ and $8.1 \%$ of the subcohort members in the lowest and highest onion consumption category, 
Table 2. RRs and $95 \%$ Confidence Intervals of Stomach Carcinoma According to Allium Vegetable Consumption and Garlic Supplement Use

\begin{tabular}{|c|c|c|c|c|c|}
\hline \multirow[b]{3}{*}{ Allium consumption } & \multirow{3}{*}{$\begin{array}{l}\text { No. of } \\
\text { cases }\end{array}$} & \multirow{3}{*}{$\begin{array}{c}\text { Person-years in } \\
\text { subcohort }\end{array}$} & \multirow[b]{2}{*}{$\begin{array}{l}\text { Stratified } \\
\text { analysis }^{a}\end{array}$} & \multicolumn{2}{|c|}{ Multivariable analysis ${ }^{b}$} \\
\hline & & & & All cases & $\begin{array}{l}\text { Excluding cases } \\
\text { from first year }\end{array}$ \\
\hline & & & $\mathrm{RR}_{\mathrm{MH}}(95 \% \mathrm{Cl})$ & $\mathrm{RR}(95 \% \mathrm{Cl})$ & $\mathrm{RR}(95 \% \mathrm{Cl})$ \\
\hline \multicolumn{6}{|l|}{ Onions (no./day) } \\
\hline 0 & 40 & 2090 & $1.00^{c}$ & $1.00^{c}$ & $1.00^{c}$ \\
\hline$\leq 0.25$ & 41 & 2978 & $0.75(0.48-1.21)$ & $0.68(0.42-1.07)$ & $0.68(0.43-1.08)$ \\
\hline $0.25-0.5$ & 44 & 3559 & $0.71(0.45-1.12)$ & $0.70(0.44-1.11)$ & $0.70(0.44-1.11)$ \\
\hline$\geq 0.5$ & 14 & 1471 & $0.44(0.23-0.86)$ & $0.50(0.26-0.95)$ & $0.50(0.26-0.96)$ \\
\hline Trend test $\chi^{2}(P$ value $)$ & & & $5.35(0.02)$ & $4.64(0.03)$ & $4.58(0.03)$ \\
\hline \multicolumn{6}{|l|}{ Leek consumption (frequency/mo) } \\
\hline 0 & 46 & 3097 & $1.00^{c}$ & $1.00^{c}$ & $1.00^{c}$ \\
\hline$\leq 2$ & 66 & 3907 & $1.07(0.72-1.60)$ & $1.23(0.83-1.84)$ & $1.23(0.82-1.83)$ \\
\hline$>2$ & 27 & 3094 & $0.61(0.37-1.01)$ & $0.69(0.42-1.14)$ & $0.69(0.42-1.15)$ \\
\hline Trend test $\chi^{2}(P$ value $)$ & & & $3.52(0.06)$ & $1.47(0.23)$ & $1.47(0.22)$ \\
\hline \multicolumn{6}{|l|}{ Garlic supplement use } \\
\hline No supplements & 118 & 7676 & $1.00^{c}$ & $1.00^{c}$ & $1.00^{c}$ \\
\hline Exclusively garlic & 9 & 490 & $1.22(0.60-2.50)$ & $1.27(0.61-2.64)$ & $1.29(0.62-2.67)$ \\
\hline Any other supplement & 20 & 2182 & $1.00^{c}$ & $1.00^{c}$ & $1.00^{c}$ \\
\hline Garlic + any other supplement & 5 & 450 & $1.18(0.42-3.34)$ & $1.28(0.45-3.66)$ & $1.28(0.43-3.86)$ \\
\hline
\end{tabular}

$\mathrm{Cl}$, confidence interval.

aStratified by sex and age in three categories (55-59, 60-64, and 65-69 years).

${ }^{b}$ Adjusted for age, alcohol intake, vitamin $C$ intake, and $\beta$-carotene as continuous variables and sex, smoking status (never, ex-smoker, or current smoker), education (primary school, low vocational level, medium vocational level, or higher vocational level/university), history of stomach disorders (yes, no), and family history of stomach cancer (yes, no) as categorical variables. The RRs with garlic supplement use are also adjusted for onion and leek consumption.

${ }^{c}$ Reference category.

respectively, reported a history of stomach cancer in parents or siblings. These percentages were $6.6 \%$ and $6.1 \%$ in the lowest and highest leek consumption category and $7.0 \%$ and $5.8 \%$ for nonusers of dietary supplements and users of garlic supplements, respectively.

RRs and $95 \%$ confidence intervals for stomach carcinoma associated with consumption of onions, leeks, and the use of garlic supplements are presented in Table 2. Onion consumption was inversely associated with stomach carcinoma risk in the age/sex-adjusted stratified analysis with a statistically significant test for trend. The RRs observed after additional adjustment for confounding in the multivariable analysis were slightly different from those observed in the stratified analysis, but the test for trend remained statistically significant. The RR for stomach carcinoma associated with leek consumption was only lower than one in the highest consumption category, but there was no clear decreasing trend with increasing consumption. The RRs associated with garlic supplement use were slightly higher than one. All analyses have also been performed after exclusion of cases diagnosed during the first year of follow-up. The results were virtually similar to those based on the entire group.
For the analyses on topographic subsites presented in Table 3, we evaluated the tumors originating from the cardia separately, whereas tumors from all other sites were combined in one group. Onion consumption was not negatively associated with risk for cardia carcinoma; all RRs in increasing categories of consumption were higher than one but not significantly different from unity. The test for trend was also not statistically significant. In contrast, the risk for noncardia carcinoma showed a rather strong inverse association with onion consumption; all RRs in increasing consumption categories were significantly below unity $(0.54,0.54$, and 0.31$)$ with a highly significant trend test. The RRs for cardia carcinoma were slightly higher among subjects without a history of gastric disorders, but none of the RRs were significantly different from unity. All RRs for noncardia carcinoma stayed below one in this subgroup, but only the RR in the highest consumption category was significantly different from unity. The trend was statistically significant.

Leek consumption was not associated with risk for carcinoma at either of these sites. The RRs for cardia carcinoma were somewhat lower than one, but none of 
Table 3. RRs and 95\% Confidence Intervals of Cardia Carcinoma and Other Subsites of Stomach Carcinoma According to Onion and Leek Consumption

\begin{tabular}{|c|c|c|c|c|c|c|c|c|}
\hline \multirow{3}{*}{$\begin{array}{c}\text { Allium } \\
\text { consumption }\end{array}$} & \multicolumn{4}{|c|}{ All $^{a}$} & \multicolumn{4}{|c|}{ Without history of gastric disorders ${ }^{b}$} \\
\hline & \multicolumn{2}{|r|}{ Cardia } & \multicolumn{2}{|r|}{ Other sites } & \multicolumn{2}{|r|}{ Cardia } & \multicolumn{2}{|r|}{ Other sites } \\
\hline & $\mathrm{n}$ & $\mathrm{RR}(95 \% \mathrm{Cl})$ & $\mathrm{n}$ & $\mathrm{RR}(95 \% \mathrm{Cl})$ & $n$ & $\mathrm{RR}(95 \% \mathrm{Cl})$ & $\mathrm{n}$ & $\mathrm{RR}(95 \% \mathrm{Cl})$ \\
\hline \multicolumn{9}{|l|}{ Onions (no./day) } \\
\hline 0 & 5 & $1.00^{c}$ & 35 & $1.00^{c}$ & 4 & $1.00^{c}$ & 25 & $1.00^{c}$ \\
\hline$\leq 0.25$ & 12 & $1.39(0.51-3.77)$ & 29 & $0.54(0.32-0.91)$ & 9 & $1.30(0.42-3.93)$ & 25 & $0.64(0.35-1.15)$ \\
\hline $0.25-0.5$ & 13 & $1.57(0.58-4.27)$ & 31 & $0.54(0.32-0.91)$ & 11 & $1.60(0.53-4.81)$ & 27 & $0.60(0.33-1.07)$ \\
\hline$\geq 0.5$ & 6 & $1.89(0.59-5.96)$ & 8 & $0.31(0.14-0.70)$ & 6 & $2.12(0.60-7.48)$ & 7 & $0.35(0.15-0.86)$ \\
\hline Trend test $\chi^{2}(P$ value $)$ & & $1.26(0.26)$ & & $10.1(0.002)$ & & $1.57(0.21)$ & & $6.04(0.01)$ \\
\hline \multicolumn{9}{|c|}{ Leek consumption (frequency/mo) } \\
\hline 0 & 13 & $1.00^{c}$ & 33 & $1.00^{c}$ & 11 & $1.00^{c}$ & 28 & $1.00^{c}$ \\
\hline$\leq 2$ & 14 & $0.85(0.40-1.81)$ & 52 & $1.37(0.86-2.17)$ & 12 & $0.79(0.37-1.70)$ & 42 & $1.17(0.73-1.86)$ \\
\hline$>2$ & 9 & $0.89(0.38-2.05)$ & 18 & $0.63(0.34-1.16)$ & 7 & $0.86(0.37-1.98)$ & 14 & 0.59 (0.32-1.09) \\
\hline Trend text $\chi^{2}(P$ value $)$ & & $0.10(0.75)$ & & $1.46(0.23)$ & & $0.17(0.68)$ & & $2.25(0.13)$ \\
\hline
\end{tabular}

${ }^{a}$ Adjusted for age, alcohol intake, vitamin $\mathrm{C}$ intake, and $\beta$-carotene as continuous variables and sex, smoking status (never, ex-smoker, or current smoker), education (primary school, low vocational level, medium vocational level, higher vocational level, or university), history of stomach disorders (yes, no), and family history of stomach cancer (yes, no) as categorical variables.

${ }^{b}$ Adjusted for age, alcohol intake, vitamin $C$ intake, and $\beta$-carotene as continuous variables and sex, smoking status (never, ex-smoker, or current smoker), education (primary school, low vocational level, medium vocational level, higher vocational level, or university), and family history of stomach cancer (yes, no) as categorical variables.

${ }^{c}$ Reference category.

the RRs were significantly different from unity and the trend was also not significant. For those who never had a gastric disorder, the RRs were somewhat lower than those observed for the entire group. For noncardia carcinoma, only the RR in the highest consumption category was lower than one both in the entire population as well as in the subgroup without gastric disorders in their medical history. None of the RRs were significantly different from one, and the test for trend was also not significant. Exclusion of cases from the first year of follow-up did not affect any of the RR estimates (data not shown). Because of the small numbers, we were not able to evaluate risks for cancer at these sites associated with garlic supplement use.

\section{Discussion}

The NLCS is the first prospective cohort study evaluating the association between consumption of onions and leeks, the use of garlic supplements, and the incidence of stomach carcinoma. We present evidence for a strongly decreased risk with increasing consumption of onions for carcinoma arising from the part of the stomach beyond the cardia. The reduced risk was also observed among those subjects who did not report having a gastric disease. Leek consumption was not associated with a lower stomach carcinoma risk in our study, and we also found no reduced risk with garlic supplement use.

To date, the evidence for a protective effect of onions on gastric cancer risk was only based on results from case-control studies mentioning allium vegetables as a separate vegetable group. The results of these studies are summarized in Table 4.

Onion intake was associated with a reduced stomach cancer risk in most of the studies, with odds ratios (ORs) ranging from 0.30 in Belgium ${ }^{28}$ and 0.31 among Hawaiian Japanese ${ }^{18}$ to 0.72 in Poland. ${ }^{27}$ In the study by You et al. ${ }^{20-22}$ in a province of China with high stomach cancer rates, not only overall allium vegetable consumption was inversely related to stomach cancer risk $^{22}$ but also consumption of specific allium vegetables. ${ }^{21}$ The lowest risk was reported for Chinese chives (OR of 0.6 in the highest intake category; $>3.7 \mathrm{~kg} / \mathrm{yr}) .{ }^{20-22}$ In Italy, increasing consumption of "onions and/or garlic as condiments" was associated with a reduced risk for stomach carcinoma and, although only information from $27 \%$ of the case patients and controls regarding garlic consumption was available, a statistically significant protective effect of cooked garlic on stomach cancer risk was also reported. ${ }^{23}$ The ORs for subsites within the stomach were not significantly different from one. ${ }^{25}$ The positive association with high onion intake in the study by Tajima and Tominaga in Japan may be explained by the selection of hospital patients with severe gastric diseases as controls. ${ }^{32}$ In the other case-control studies using hospital controls, patients with stomach disorders ${ }^{18,27,30}$ or those requiring a special diet ${ }^{19,31}$ were excluded. 
Table 4. Case-Control Studies of Allium Vegetables and Stomach Cancer

\begin{tabular}{|c|c|c|c|c|c|}
\hline Author, year (location) & $\begin{array}{l}\text { Case patients/ } \\
\text { controls }\end{array}$ & $\begin{array}{l}\text { Time of } \\
\text { reference }\end{array}$ & Allium vegetable (units) & Comparison & OR/outcome \\
\hline $\begin{array}{l}\text { Haenszel, } 1972 \\
\text { (Hawaii) }^{18}\end{array}$ & 220/440 (hospital) & Current diet & $\begin{array}{l}\text { (Green) onion } \\
\text { (frequency/mo) }\end{array}$ & $\begin{array}{l}\text { Tertiles: } \\
<8,8-20, \geq 21\end{array}$ & $\begin{array}{c}\text { Japanese born: 1.0, } \\
0.91,0.67^{a} \\
\text { Hawaiian born: 1.0, } \\
0.67,0.31^{a}\end{array}$ \\
\hline Tajima, 1985 (Japan) & 93/186 (hospital) & $\begin{array}{l}\text { 1-2 yr before } \\
\text { diagnosis }\end{array}$ & Onion (frequency/wk) & $\begin{array}{l}\text { Tertiles: }<1,1-3, \geq 4 \\
\geq 1 \text { vs. }<1\end{array}$ & $\begin{array}{l}\text { 1.0, } 1.15,2.13^{b} \\
\text { All: } 1.36 \\
\text { Age } 40-55 \text { yr: } 1.41 \\
\text { Age } 56-70 \text { yr: } 1.31\end{array}$ \\
\hline $\begin{array}{l}\text { Trichopoulos, } 1985 \\
(\text { Greece) })^{19}\end{array}$ & 110/100 (hospital) & Before disease & Onion (frequency/mo) & $\begin{array}{l}0,2,4,10,30 \\
1 / \text { wk vs. } 2 / \text { wk }\end{array}$ & $\begin{array}{l}P_{\text {Trend }}<0.001^{c} \\
0.68^{c}\end{array}$ \\
\hline $\mathrm{Hu}, 1988$ (China) $^{30}$ & 241/241 (hospital) & $\begin{array}{l}\text { Before disease } \\
\text { and before } \\
1966\end{array}$ & $\begin{array}{l}\text { Chives (kg/yr) } \\
\text { Onion }(\mathrm{kg} / \mathrm{yr})\end{array}$ & $\begin{array}{l}\text { Not specified } \\
\text { Not specified }\end{array}$ & $\begin{array}{l}\text { 1984: } P>0.5 \\
\text { 1966: } P>0.2 \\
\text { 1984: } P>0.5 \\
\text { 1966: } P>0.5\end{array}$ \\
\hline \multirow[t]{6}{*}{$\begin{array}{l}\text { You, } 1988,1989 \\
1991 \text { (China) }\end{array}$} & $\begin{array}{l}\text { 564/1131 } \\
\quad \text { (population) }\end{array}$ & $\begin{array}{l}4-6 \text { yr before } \\
\text { interview }\end{array}$ & Allium vegetables (kg/yr) & $\begin{array}{l}\text { Quartiles: } \leq 11.5, \\
\text { 11.6-16.5, } \\
16.6-24.0,>24.0\end{array}$ & $1.0,0.7,0.7,0.5^{c}$ \\
\hline & & & Scallion (kg/yr) & $\begin{array}{l}\text { Tertiles: } \leq 9.0 \\
\quad 9.1-18.0,>18.0\end{array}$ & $1.0,1.0,0.8^{b, c}$ \\
\hline & & & Garlic (kg/yr) & $\begin{array}{l}\text { Tertiles: } 0,0.1-1.5 \\
>1.5\end{array}$ & $1.0,0.8,0.7^{b, c}$ \\
\hline & & & Garlic stalks (kg/yr) & $\begin{array}{l}\text { Tertiles: } 0,0.1-0.5 \text {, } \\
>0.5\end{array}$ & $1.0,1.0,0.7^{c}$ \\
\hline & & & Chinese chives (kg/yr) & $\begin{array}{l}\text { Tertiles: }<1.5 \\
1.6-3.7,>3.7\end{array}$ & $1.0,0.7,0.6^{b, c}$ \\
\hline & & & Onion (kg/yr) & $\begin{array}{l}\text { Tertiles: } 0,0.1-0.5 \\
\quad>0.5\end{array}$ & $1.0,0.8,1.0^{c}$ \\
\hline \multirow[t]{4}{*}{$\begin{array}{l}\text { Buiatti, 1989; Cipriani, } \\
\text { 1991; Palli, } 1992 \\
(\text { Italy })^{23-25}\end{array}$} & $\begin{array}{l}\text { 1016/1159 } \\
\text { (population) }\end{array}$ & $\begin{array}{l}2 \text { yr before } \\
\text { interview }\end{array}$ & $\begin{array}{l}\text { Onion + garlic as condi- } \\
\text { ment (frequency/wk) }\end{array}$ & $\begin{array}{l}\text { Tertiles: } \\
1.2,4.6,7.2\end{array}$ & $\begin{array}{l}\text { All cancer: } 1.0,1.0 \text {, } \\
\quad 0.8^{b} \\
\text { Intestinal type: } 0.9 \\
\text { Diffuse type: } 0.7 \\
\text { Mixed type: } 0.7 \\
\text { Cardia: } 0.7 \\
\text { Other sites: } 0.8\end{array}$ \\
\hline & & & Raw onion (freq/wk) & Tertiles & $1.0,1.0,0.8^{b}$ \\
\hline & & & Cooked onion & $>1 / \mathrm{m}$ vs. $<1 / \mathrm{m}$ & 1.1 \\
\hline & $\begin{array}{l}27 \% \text { of study } \\
\text { population }\end{array}$ & & Cooked garlic (freq/wk) & Tertiles & $1.0,0.6,0.4^{b}$ \\
\hline $\begin{array}{l}\text { Graham, } 1990 \\
\left(_{\text {New York })^{26}}\right.\end{array}$ & $\begin{array}{l}293 / 293 \\
\quad \text { (neighborhood) }\end{array}$ & $\begin{array}{l}1 \text { yr before } \\
\text { symptoms }\end{array}$ & $\begin{array}{l}\text { Onion (cooked + raw) } \\
\quad \text { (frequency/mo) }\end{array}$ & Not specified & $\begin{array}{l}\text { "sign. decreasing } \\
\text { risk in male and } \\
\text { female" }\end{array}$ \\
\hline $\begin{array}{l}\text { Boeing, } 1991 \\
\quad(\text { Poland })^{27}\end{array}$ & 741/741 (hospital) & $\begin{array}{l}\text { Before } \\
\text { symptoms }\end{array}$ & Onion (frequency) & Tertiles & $1.0,0.88,0.86^{c}$ \\
\hline \multirow[t]{2}{*}{$\begin{array}{l}\text { Gonzalez, } 1991 \\
(\text { Spain })^{31}\end{array}$} & 354/354 (hospital) & $\begin{array}{l}1 \text { yr before } \\
\text { disease }\end{array}$ & Raw onion & High vs. low & 0.9 \\
\hline & & & Garlic as seasoning & Frequency & No association \\
\hline $\begin{array}{l}\text { Tuyns, } 1992 \\
\text { (Belgium) }\end{array}$ & $\begin{array}{l}\text { 449/3524 } \\
\text { (population) }\end{array}$ & Before disease & $\begin{array}{l}\text { Cooked onion } \\
\text { Cooked leek }\end{array}$ & $\begin{array}{l}\text { Yes vs. no } \\
\text { Yes vs. no }\end{array}$ & $\begin{array}{l}0.30^{a, c} \\
0.29^{a, c}\end{array}$ \\
\hline \multirow[t]{3}{*}{$\begin{array}{l}\text { Hansson, 1993, } \\
{\text { (Sweden })^{29}}^{\text {(Sw }}\end{array}$} & $\begin{array}{l}338 / 669 \\
\text { (population) }\end{array}$ & $\begin{array}{c}20 \mathrm{yr} \text { before } \\
\text { interview }\end{array}$ & Onion (frequency/mo) & $0,3,7,11$ & $\begin{array}{l}\text { 1.0, } 0.84,0.83 \\
\quad 0.84\end{array}$ \\
\hline & & & Leek (frequency/mo) & $0,0.9,3$ & $1.0,0.76,0.63^{a, b}$ \\
\hline & & & Garlic (frequency/mo) & Yes vs. no & 0.89 \\
\hline
\end{tabular}

${ }^{a} 95 \%$ confidence interval does not include 1.00 .

${ }^{b}$ Statistically significant trend.

${ }^{c}$ Adjusted for other food items.

One of the strengths of our cohort study is that the completeness of follow-up is very high. ${ }^{39}$ Consequently, the results cannot be explained by exposure-related loss to follow-up. Furthermore, we controlled for potential confounding by including important nondietary as well as dietary (vitamin $C$ and $\beta$-carotene) risk factors of stomach carcinoma in the multivariable models. Because none of the RR estimates was markedly changed, it is unlikely 
that residual confounding due to inaccuracies in the measurements of these factors explain the results. Nevertheless, it might still be possible that another factor is involved. In the studies by Trichopoulos et al., ${ }^{19}$ You et al., ${ }^{20-22}$ and Tuyns et al., ${ }^{28}$ showing significantly lower risks with allium vegetable consumption, the ORs were also adjusted for dietary risk factors. In the large casecontrol study in Italy, the ORs were only adjusted for nondietary risk factors. ${ }^{23-25}$ In the study by Boeing et al., ${ }^{27}$ onion consumption was no longer significantly associated with a lower stomach cancer risk after additional adjustment for vegetables and fruit.

One of the other strengths of our study is that we measured diet before the disease was diagnosed and thus avoided the problem of biased recall inherent in the casecontrol study design. A potential drawback is the still limited length of follow-up (3.3 years). Because duration of several years of preclinical symptoms of stomach carcinoma, most often abdominal discomfort of insidious onset, is not uncommon, ${ }^{35}$ case patients may have altered their dietary habits in the course of time before baseline. Categorization of the cases by year of follow-up indeed showed that case patients from the first follow-up year had onion consumption less like members from the subcohort than case patients from later follow-up years. However, exclusion of case patients diagnosed in the first follow-up year only marginally changed the results. Nevertheless, a 1-year period may not be long enough. To study this problem in more detail, a longer followup period will be required. In case-control studies, it is equally important to measure dietary intake in the correct reference period. However, only in the studies by Graham et al. $^{26}$ and Boeing et al., ${ }^{27}$ the reference period was defined as the time before onset of symptoms of the disease.

A potential limitation of our study is that we cannot rule out the possibility of nondifferential misclassification of exposure. Although the semiquantitative food frequency questionnaire was validated, specific information on the validity of the report of onion and leek consumption is not available. ${ }^{36}$ If nondifferential misclassification with respect to onion and leek consumption has occurred, the actual RRs may be stronger than those we have observed. For garlic supplements, it is unlikely that this explains absence of an effect of garlic supplements because the agreement between interview data and the open-ended question on dietary supplement use was relatively high (77.8\% recall). ${ }^{41}$

In the NLCS cohort, we could not evaluate whether the risk for stomach carcinoma varied with raw or cooked onions and leeks because we did not inquire after the preparation methods in our questionnaire. It might be important to collect information on preparation methods, although results from the case-control studies are scarce and yet inconsistent. ${ }^{23,28,31}$ However, it has been shown that the levels of potentially chemopreventive compounds depend on the preparation methods. ${ }^{8,10,49,50}$

Garlic and onion extracts, but also synthetically produced organosulfur compounds, have not only been shown to inhibit mutagenesis, initiation, and promotion but also to induce enzymes important in the detoxification of carcinogens. ${ }^{8,51,52}$ However, because the evidence that Helicobacter pylori is one of the important independent risk factors for the noncardia part of the stomach cancer is growing, ${ }^{4,53-56}$ the original observation that these compounds act antibacterially ${ }^{5}$ may be even more interesting and should be further investigated. ${ }^{56}$

In conclusion, we found evidence for a reduced risk of carcinoma in all parts of the stomach, except in the cardia, with increased consumption of onions. The reduced risk was also observed among those without a gastric disorder in their medical history. No association was observed for leek consumption or the use of garlic supplements. Exclusion of case patients diagnosed during the first year of follow-up gave similar results as those based on the entire case group.

\section{References}

1. Steinmetz K, Potter JD. Vegetables, fruit, and cancer. I. Epidemiology. Cancer Causes Control 1991;2:325-357.

2. Block G, Patterson B, Subar A. Fruit, vegetables, and cancer prevention: a review of the epidemiological evidence. Nutr Cancer 1992;18:1-29.

3. Boeing $\mathrm{H}$. Epidemiological research in stomach cancer: progress over the last ten years. J Cancer Res Clin Oncol 1991;117:133143.

4. Nomura A, Stemmermann GN. Helicobacter pylori and gastric cancer. J Gastroenterol Hepatol 1993; 8:294-303.

5. Cavallito $\mathrm{CJ}$, Bailey JH. Allicin, the antibacterial principle of allium sativum. I. Isolation, physical properties and antibacterial action. J Am Chem Soc 1944;66:1950-1951.

6. Fenwick GR, Hanley AB. The genus Allium, part 3. CRC Crit Rev Food Sci Nutr 1986;23:1-73.

7. Hughes BG, Lawson LD. Antimicrobial effects of Allium sativum L. (Garlic), Allium ampeloprasum L. (Elephant garlic), and Allium cepa L. (onion), garlic compounds and commercial garlic supplement products. Phytother Res 1991;5:154-158.

8. Dorant E, Van den Brandt PA, Goldbohm RA, Hermus RJJ, Sturmans F. Garlic and its significance for the prevention of cancer in humans: a critical view. Br J Cancer 1993;67:424-429.

9. Lawson LD, Wang ZYJ, Hughes BG. Identification and HPLC Quantification of the sulfides and dialk(en)yl thiosulfinates in commercial garlic products. Planta Med 1991;57:363-370.

10. Block E. The organosulfur chemistry of the Genus Allium-implications for the organic chemistry of sulfur. Angew Chem Int Ed Engl 1992;31:1135-1178.

11. Dorant E, Van den Brandt PA, Hamstra AM, Feenstra MH, Goldbohm RA, Hermus RJJ, Sturmans F. The use of vitamins, minerals 
and other dietary supplements in The Netherlands. Int J Vit Nutr Res 1993;63:4-10.

12. Newmark HL. Plant phenolics as inhibitors of mutational and precarcinogenic events. Can J Physiol Pharmacol 1987;65:461466.

13. Steinmetz K, Potter JD. Vegetables, fruit, and cancer. II. Mechanisms. Cancer Causes Control 1991;2:427-442.

14. Bilyk A, Sapers GM. Distribution of quercetin and kaempferol in lettuce, kale, chive, garlic chive, leek, horseradish, red radish, and red cabbage tissues. J Agric Food Chem 1985;33:226228.

15. Jones DP, Coates RJ, Flagg EW, Eley JW, Block G, Greenberg RS, Gunter EW, Jackson B. Glutathione in foods listed in the National Cancer Institute's Health Habits and History Food Frequency Questionnaire. Nutr Cancer 1992;17:57-75.

16. Coles B, Ketterer B. The role of glutathione and glutathione transferases in chemical carcinogenesis. Crit Rev Biochem Mol Biol 1990; 25:47-70.

17. Hertog MGL, Hollman $\mathrm{CH}$, Katan MB. Content of potentially anticarcinogenic flavonoids of 28 vegetables and 9 fruits commonly consumed in The Netherlands. J Agric Food Chem 1992; 40:2379-2383.

18. Haenszel W, Kurihara M, Segi M, Lee RKC. Stomach cancer among Japanese in Hawaii. J Natl Cancer Inst 1972;49:969988.

19. Trichopoulos D, Ouranos G, Day NE, Tzonou A, Manousos O, Papadimitriou Ch, Trichopoulos A. Diet and cancer of the stomach: a case-control study in Greece. Int J Cancer 1985;36:291297.

20. You W, Blot WJ, Chang Y, Ershow AG, Yang Z, An Q, Henderson B, Xu G, Fraumeni JF, Wang T. Diet and high risk of stomach cancer in Shandong, China. Cancer Res 1988;48:3518-3523.

21. You W, Blot WJ, Chang Y, Ershow AG, Yang Z, An Q, Henderson $\mathrm{B}, \mathrm{X}$ U G, Fraumeni JF, Wang T. Allium vegetables and reduced risk of stomach cancer. J Natl Cancer Inst 1989;81:162-164.

22. You WC, Chang YS, Yang ZT, Zhang L, Xu GW, Blot WJ, Kneller $\mathrm{R}$, Keefer LK, Fraumeni JF. Etiological research on gastric cancer and its precursor lesions in Shandong, China. In: O'Neill IK, Chen $\mathrm{J}$, Bartsch $\mathrm{H}$, eds. Relevance to human cancer of $\mathrm{N}$-nitroso compounds, tobacco smoke and mycotoxins. Lyon International Agency for Research on Cancer, 1991: 33-38.

23. Buiatti E, Palli D, Decarli A, Amadori D, Avellini C, Bianchi S, Biserni R, Cipriani F, Cocco P, Giacosa A, Marubini E, Puntoni R, Vindigni C, Fraumeni J, Blot W. A case-control study of gastric cancer and diet in Italy. Int J Cancer 1989;44:611-616.

24. Cipriani F, Buiatti E, Palli D. Gastric cancer in Italy. Ital J Gastroenterol 1991;23:429-435.

25. Palli D, Bianchi S, Decarli A, Cipriani F, Avellini C, Cocco P, Falcini F, Puntoni R, Russo A, Vindigni C, Fraumeni JF, Blot WJ, Buiatti $\mathrm{E}$. A case-control study of cancer of the gastric cardia in Italy. $\mathrm{Br}$ J Cancer 1992;65:263-266.

26. Graham S, Haughey B, Marshall J, Brasure J, Zielezny M, Freudenheim J, West D, Nolan J, Wilkinson G. Diet in the epidemiology of gastric cancer. Nutr Cancer 1990;13:19-34.

27. Boeing $H$, Jedrychowski, Wahrendorf J, Popiela T, Tobiasz-Adamczyk B, Kulig A. Dietary risk factors in intestinal and diffuse types of stomach cancer: a multicenter case-control study in Poland. Cancer Causes Control 1991;2:227-233.

28. Tuyns AJ, Kaaks R, Haelterman M, Riboli E. Diet and gastric cancer. A case-control study in Belgium. Int J Cancer 1992;51:16.

29. Hansson LE, Nyren O, Bergstrom R, Wolk A, Lindgren A, Baron $\mathrm{J}$, Adami HO. Diet and risk of gastric cancer. A population-based case-control study in Sweden. Int J Cancer 1993;55:181-189.

30. Hu J, Zhang S, Jia E, Wang E, Liu S, Liu Y, Wu Y, Cheng Y. Diet and cancer of the stomach: a case-control study in China. Int J Cancer 1988; 41:331-335.

31. Gonzalez CA, Sanz JM, Marcos G, Pita S, Brullet E, Saigi E, Badia, A, Riboli E. Dietary factors and stomach cancer in Spain: a multicentre case-control study. Int J Cancer 1991;49:513-519.

32. Tajima K, Tominaga S. Dietary habits and gastro-intestinal cancers: a comparative case-control study of stomach and large intestinal cancers in Nagoya, Japan. Jpn J Cancer Res (Gann) 1985; 76:705-716.

33. Rothman KJ. Modern epidemiology. Boston: Little, Brown and Company, 1986.

34. Møller Jensen O, Wahrendorf J, Rosenqvist A, Geser A. The reliability of questionnaire-derived historical dietary information and temporal stability of food habits in individuals. Am J Epidemiol 1984;120:281-290.

35. MacDonald WC, Rubin CE. Cancer, benign tumors, gastritis and other gastric disease. In: Isselbacher KJ, Adams RD, Braunwald E, Petersdorf RG, Wilson JD, eds. Harrison's principles of internal medicine. 9th ed. Tokyo, Japan: McGraw-Hill Kogakusha Ltd., 1980.

36. Koch JP, Donaldson RM. A survey of food intolerances in hospitalized patients. N Engl J Med 1964;271:657-660.

37. Van den Brandt PA, Goldbohm RA, Van't Veer P, Volovics A, Hermus RJJ, Sturmans F. A large-scale prospective cohort study on diet and cancer in The Netherlands. J Clin Epidemiol 1990; 43:285-295.

38. Van den Brandt PA, Schouten LJ, Goldbohm RA, Dorant E, Hunen $\mathrm{PMH}$. Development of a record linkage protocol for use in the Dutch Cancer registry for epidemiological research. Int J Epidemiol 1990;19:553-558.

39. Van den Brandt PA, Van't Veer P, Goldbohm RA, Dorant E, Volovics A, Hermus RJJ, Sturmans F. A prospective cohort study on dietary fat and the risk of postmenopausal breast cancer. Cancer Res 1993; 53:75-82.

40. Goldbohm RA, Van den Brandt PA, Brants HAM, Van't Veer P, Al $M$, Sturmans F, Hermus RJJ. Validation of a dietary questionnaire used in a large-scale prospective cohort study on diet and cancer. Eur J Clin Nutr 1994;48:253-265.

41. Dorant E, Van den Brandt PA, Goldbohm RA, Hermus RJJ, Sturmans F. Agreement between interview data and a self-administered questionnaire on dietary supplement use. Eur J Clin Nutr 1994;48:180-188.

42. Self SG, Prentice RL. Asymptotic distribution theory and efficiency results for case-cohort studies. Ann Stat 1988;16:64-81.

43. Stichting NEVO. NEVO table; Dutch food composition table 1986-1987. The Hague, Netherlands: Voorlichtingsbureau voor de Voeding, 1986.

44. MacDonald WC, MacDonald JB. Adenocarcinoma of the esophagus and/or gastric cardia. Cancer 1987;60:1094-1098.

45. International Classification of Diseases for Oncology. 1st ed. Geneva: World Health Organization, 1976.

46. Correa P. A human model of gastric carcinogenesis. Cancer Res 1988;48:3554-3560.

47. Dorant E, Van den Brandt PA, Goldbohm RA. A prospective cohort study on Allium vegetable consumption, garlic supplement use,and the risk of lung carcinoma in The Netherlands. Cancer Res 1994; 54:6148-6153.

48. Dorant E, Van den Brandt PA, Goldbohm RA. Allium vegetable consumption, garlic supplement intake and female breast carcinoma incidence. Breast Cancer Res Treat 1995;33:163-170.

49. Starke H, Herrmann K. Flavonols and flavones of vegetables. VI. On the changes of flavonols of onions. Z Lebensm Unters Forsch 1976;161:137-142.

50. Starke H, Herrmann K. Flavonols and flavones of vegetables. VII. Flavonols of leek, chive and garlic. Z Lebensm Unters Forsch 1976;161:25-30. 
51. Maurya AK, Singh SV. Differential induction of glutathione transferase isoenzymes of mice stomach by diallyl sulfide, a naturally occurring anticarcinogen. Cancer Lett 1991;57:121-129.

52. Shenoy NR, Choughuley ASU. Inhibitory effect of diet related sulphydryl compounds on the formation of carcinogenic nitrosamines. Cancer Lett 1992;65:227-232.

53. Parsonnet J, Friedman GD, Vandersteen DP, Chang Y, Vogelman $\mathrm{JH}$, Orentreich N, Sibley RK. Helicobacter pylori infection and the risk of gastric carcinoma. N Engl J Med 1991;325:11271131.

54. Nomura A, Stemmermann GN, Chyou PH, Kato I, Perez-Perez GI, Blaser MJ. Helicobacter pylori infection and gastric carcinoma among Japanese Americans in Hawaii. $N$ Engl J Med 1991;325:1132-1136.
55. Hansson LE, Engstrand L, Nyren O, Evans DJ, Lindgren A, Bergström R, Andersson B, Athlin L, Bendtsen O, Tracz P. Helicobacter pylori infection: independent risk indicator of gastric adenocarcinoma. Gastroenterology 1993;105:1098-1103.

56. Parsonnet J, Samloff IM, Nelson LM, Orentreich N, Vogelman JH, Friedman GD. Helicobacter pylori, pepsinogen, and risk for gastric adenocarcinoma. Cancer Epidemiol Biomarker Prev 1993; 2:461-466.

Received August 22, 1994. Accepted July 19, 1995.

Address requests for reprints to: Elisabeth Dorant, M.D., Ph.D., Department of Epidemiology, University of Limburg, P.0. Box 616, NL-6200 MD Maastricht, The Netherlands. Fax: (31) 43-361-8685. 